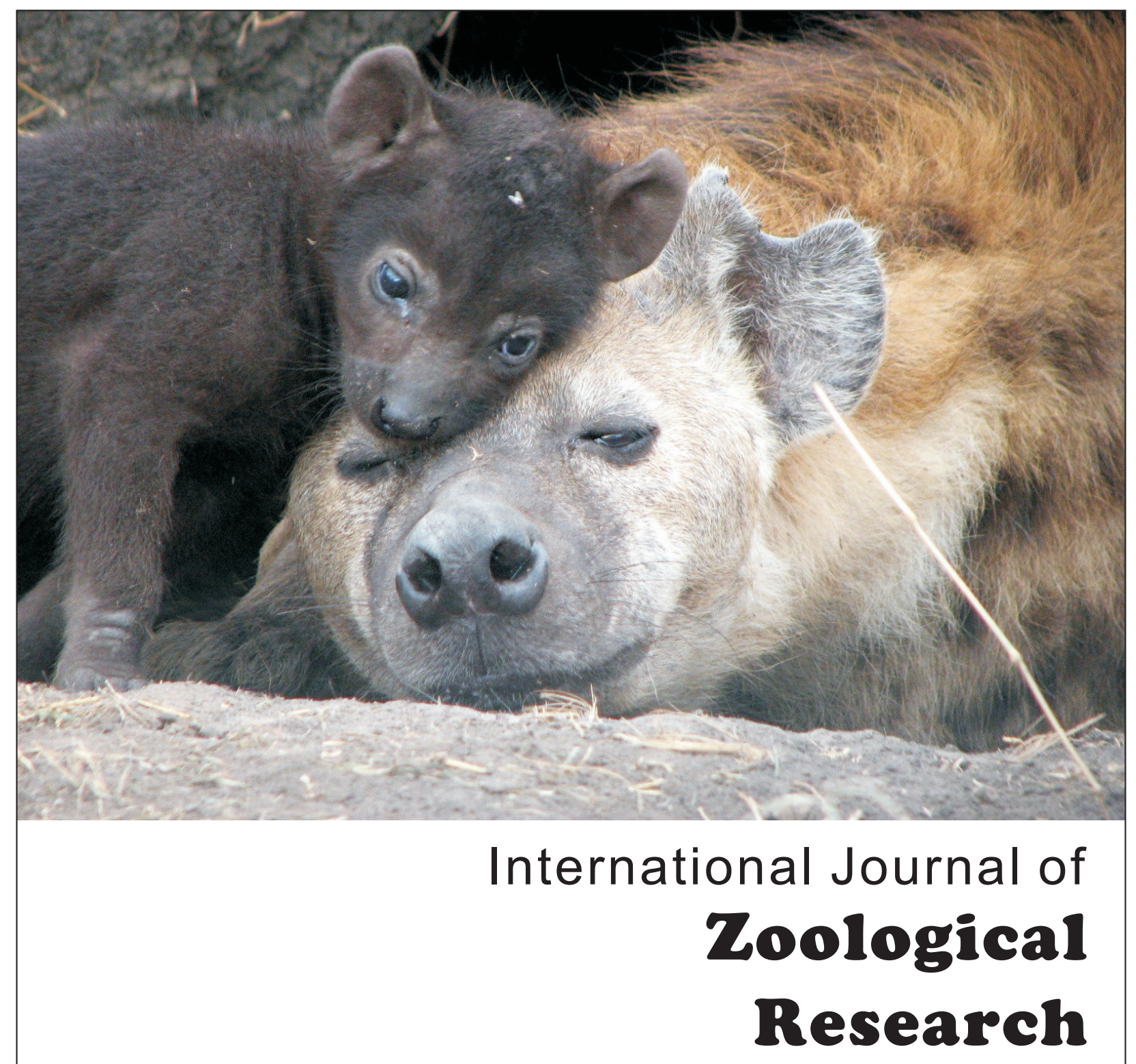

ISSN 1811-9778

\title{
(a)
}

Academic

Journals Inc. 
DOI: 10.3923/ijzr.2019.6.12

\title{
Research Article
}

\section{Protection of Protein in Cattle Feed Supplement from Rumen Microbial Degradation with Addition of Gambier Leaf Residue}

\author{
${ }^{1}$ Ramaiyulis, ${ }^{2}$ Madiati Zain, ${ }^{2}$ Rusmana Wijaya Setia Ningrat and ${ }^{2}$ Lili Warly \\ ${ }^{1}$ Agricultural Polytechnic Payakumbuh, Tanjung Pati, Limapuluh 26271, Kota, Indonesia \\ ${ }^{2}$ Department of Animal Science, Andalas University, Kampus Limau Manis, 25163, Padang, Indonesia
}

\section{Abstract}

Background and Objective: Protection of proteins is essential for productive ruminants, this study aimed to obtain optimal level of gambier leaf residue (GLR) that can protect the protein of cattle feed supplement (CFS) from rumen microbial degradation. Materials and Methods: Gambier (Uncaria gambir Roxb.) leaf residue containing 9.96\% condensed tannin was added to CFS containing $29 \%$ crude protein with a mixture of brown sugar, soybean meal, coconut cake, tapioca, urea and minerals at level 0 (control), 2.5, 5.0 and 7.5\%. Condensed tannin content in CFS: $0,0.68,1.17$ and $1.60 \%$ then which were tested in rumen digestion in vitro. Results: The addition GLR in CFS can protected protein in CFS with decreased ruminal protein degradation 16.84\% compare control. Rumen undegraded dietary protein (RUDP), TCA-soluble $\mathrm{N}$ and peptide $\mathrm{N}$ was increase by addition GLR in average $42.38 \%$ compared control. The optimum level of GLR in CFS was obtained $4.88 \%$ with the minimum rate of protein degradation in $1.05 \% \mathrm{~h}^{-1}$. Conclusion: The addition of GLR in CFS can protected protein from microbial degradation in rumen with optimum level of $4.88 \%$.

Key words: Cattle feed supplement, gambier leaf residue, tannin, protein degradation

Citation: Ramaiyulis, Madiati Zain, Rusmana Wijaya Setia Ningrat and Lili Warly, 2019. Protection of protein in cattle feed supplement from rumen microbial degradation with addition of gambier leaf residue. Int. J. Zool. Res., 15: 6-12.

Corresponding Author: Lili Warly, Department Animal Science, Andalas University, Kampus Limau Manis, 25163, Padang, Indonesia Tel:+62-81363026144

Copyright: ( 2019 Ramaiyulis et al. This is an open access article distributed under the terms of the creative commons attribution License, which permits unrestricted use, distribution and reproduction in any medium, provided the original author and source are credited.

Competing Interest: The authors have declared that no competing interest exists.

Data Availability: All relevant data are within the paper and its supporting information files. 


\section{INTRODUCTION}

Protein is a nutritional element that is needed in the growth of livestock body tissues. Protein deficiency can inhibit livestock productivity and even reduce their weight, especially in livestock that is growing, pregnant and lactating periods'. Provision of protein in ruminant livestock rations is very crucial because of the low-protein content in tropical forages $s^{2,3}$ and low-protein content in concentrates ${ }^{3}$, especially on small farms. Therefore; cattle feed supplements (CFS) are made which can supply feed protein for ruminant and support microbial protein synthesis in the rumen, but the supply of quality protein is faced with the problem of degradation of proteins in the rumen which decreases the biological value of proteins.

In ruminants, have a uniqueness in protein metabolism by rumen microbial activity. Dietary protein in the rumen will be degraded to polypeptides and amino acids and then deaminated to ammonia $\left(\mathrm{NH}_{3}\right)$ which is needed for microbial protein synthesis ${ }^{4}$. The rate of degradation is an indicator of the amount of protein from ration available for ruminant ${ }^{5}$. Protein degradation in the rumen will reduce the biological value of feed protein ${ }^{6}$, therefore proteins need to be protected so that more amino acids are available in post-rumen digestion. Protein protection needs to consider the supply of ammonia to microbes ${ }^{7,8}$, because microbial proteins are the main protein source for ruminant ${ }^{6,9}$.

Gambier leaf residue (GLR) is a waste from the extraction of gambir leaves (Uncaria gambier Roxb.) containing 9.96\% condensed tannins and potentially added to CFS for protecting proteins from microbial degradation in the rumen. Tannins are polyphenol compounds that can form complexes with proteins that are resistant to microbial degradation at neutral $\mathrm{pH}$ in the rumen ${ }^{10}$. The GLR is abundantly available from gambier industries considering that Indonesia is the main gambier producer in the world, especially West Sumatra ${ }^{11}$.

This study wanted to test the level of GLR as a protein protector to protection feed protein from rumen microbes degradation. This study aims to obtain the optimal level of GLR which results in a minimum degradation of the CFS protein in the rumen.

\section{MATERIALS AND METHODS}

This research was conducted in February-April, 2017. Analysis of the samples was carried out at the Ruminant Nutrition Laboratory of the Faculty of Animal Husbandry, Andalas University, Padang and the Payakumbuh State Agricultural Polytechnic Livestock Laboratory.
Table 1: Cattle feed supplement composition with the addition of gambier leaf residue

\begin{tabular}{|c|c|c|c|c|}
\hline \multirow[b]{2}{*}{ Ingredients } & \multicolumn{4}{|c|}{ Gambier leaf residue (DM) (\%) } \\
\hline & 0 & 2.5 & 5.0 & 7.5 \\
\hline Brown sugar & 15.00 & 15.00 & 15.00 & 15.00 \\
\hline Bran & 29.00 & 28.00 & 27.00 & 26.00 \\
\hline Coconut meal & 15.00 & 14.00 & 12.00 & 11.00 \\
\hline Soybean meal & 15.00 & 15.00 & 15.00 & 15.00 \\
\hline Tapioca & 15.00 & 15.00 & 15.00 & 15.00 \\
\hline Urea & 5.00 & 5.00 & 5.00 & 5.00 \\
\hline Salt & 3.00 & 2.50 & 3.00 & 2.50 \\
\hline Mineral & 3.00 & 3.00 & 3.00 & 3.00 \\
\hline Gambier leaf residue & 0.00 & 2.50 & 5.00 & 7.50 \\
\hline \multicolumn{5}{|l|}{ Chemical composition } \\
\hline Organic matter (\%) & 84.32 & 84.51 & 85.95 & 85.96 \\
\hline Crude protein (CP) (\%) & 29.30 & 29.36 & 29.64 & 29.90 \\
\hline Tannin (\%) & 0.00 & 0.68 & 1.17 & 1.60 \\
\hline Tannin: CP non-urea & 0.00 & 62.42 & 31.21 & 20.81 \\
\hline
\end{tabular}

Treatment ration: Cattle feed supplement made with the composition in Table 1 with 4 levels of GLR addition, namely $0 \%$ (control), 2.5, 5.0 and 7.5\% (DM) with iso-protein and energy. The GLR was taken from the gambier industrial center in Limapuluh Kota, west Sumatra, Indonesia and then dried in an oven at $60^{\circ} \mathrm{C}$ for $24 \mathrm{~h}$ and then ground into flour. Brown sugar plus $37.50 \%$ water, boiled until all the sugar is melted, then added the soybean meal, coconut meal and GLR then stirred and then mixed with all the other CFS ingredients. The dough is forming with a pellet machine and dried in an oven at $60^{\circ} \mathrm{C}$ for $24 \mathrm{~h}$.

In vitro procedure: In vitro rumen digestion was carried out follow the first stage procedure of Tilley and Terry ${ }^{12}$. Rumen fluid was obtained from the Padang city slaughterhouse originating from 4 cattle that were given grass rations. Rumen fluid is taken immediately after the cattle are slaughtered by squeezing the rumen contents using 4 layers of gauze and accommodated with a thermos that has been warmed previously by filling warm water at $40^{\circ} \mathrm{C}$ for $2 \mathrm{~min}$. Rumen liquid was mixed with a McDougall ${ }^{13}$ buffer solution at ratio 1: 4 and then poured $50 \mathrm{~mL}$ into a fermenter tube containing $0.5 \mathrm{~g}$ of CFS sample and without CFS as blank. To create an anaerobic condition, $\mathrm{CO}_{2}$ gas is sprayed for $30 \mathrm{sec}$ into the fermenter tube and immediately installed a rubber cap that has been equipped with a fermentation gas exhaust valve. Incubation was carried out in a shaker water bath at a temperature of $39^{\circ} \mathrm{C}$ with a horizontal stirring of 20 swings per minute for 3, 6, 12, 24 and $48 \mathrm{~h}$ of incubation. At the end of the incubation, the fermenter tube is soaked in cold water at $4^{\circ} \mathrm{C}$ to stop the fermentation process.

Sample analysis: The ruminal $\mathrm{pH}$ in the fermenter tube was measured with Hanna pH meter (Hi9807-phep) then the 
fermenter tube content was centrifuged at 3,000 rpm for 5 min at $4^{\circ} \mathrm{C}$. The supernatant was analyzed to determine the $\mathrm{NH}_{3}-\mathrm{N}$ concentration in rumen fluid using Conway micro diffusion method ${ }^{14}$ while the residue was washed with distilling water 3 times with centrifuges as before and then filtered with Whatman 41 filter paper, dried and weighed. Dry residues were analyzed to determine crude protein by the Kjeldahl method ${ }^{14}$. Rumen undegraded dietary protein (RUDP) is the difference between residual protein and the blank, whereas protein degradation is the percentage of difference sample protein incubated with RUDP.

TCA-soluble $\mathrm{N}$ is determined by following the procedure of Griswold', rumen fluid is homogenized by a stirrer for $2 \mathrm{~min}$, then pour $10 \mathrm{~mL}$ into a centrifuge tube and add $20 \mathrm{~mL}$ mixture of Trichloroacetic acid (TCA) $20 \%$ and Sulfosalicylic acid (SSA) $2 \%$ and leave it for $1 \mathrm{~h}$. Then centrifuged 3,000 rpm for $20 \mathrm{~min}$ at $4^{\circ} \mathrm{C}$ and the residue obtained was analyzed using the Kjeldahl method ${ }^{14}$. TCA-soluble $\mathrm{N}$ is estimated containing nitrogen from peptides, amino acids and $\mathrm{NH}_{3}-\mathrm{N}$, so the peptide can be determined after correction with $\mathrm{NH}_{3}-\mathrm{N}$.

Statistical analysis: The data were analyzed statistically using a one-way analysis of variance (ANOVA) by IBM SPSS Statistics 24 Core System ${ }^{15}$ by F-test and indicated by their p-value. If the treatment effect was significant, differences among treatments were determined using Tukey's multiple comparison procedure. Standard errors of the means and $p$-value were reported and effects were considered significant at a probability of $p<0.05$. Regression analysis was used to determine the optimum level of GLR in CFS and to estimate the minimum rate of protein degradation in the rumen.

\section{RESULTS}

Ruminal protein degradation: In Table 2, the level of addition of GLR in CFS is statistically significant $(p<0.05)$ for all parameters. The Tukey-test showed that the protein degradation of CFS in the rumen decreased after the addition of GLR starting from the lowest level, but not significantly different from the other higher levels. The addition of GLR in the CFS decreased ruminal protein degradation in the average of $16.84 \%$ compared to the control. In Fig. 1, the protein degradation of CFS which received additional GLR was consistently lower than the control at all observed incubation times.

The addition of GLR can protect the CFS protein from rumen degradation because of the condensed tannin content in GLR. Multiple regression analysis showed the protein degradation in the rumen significantly decreased linearly due to an increase in tannin level $\left(x_{1}\right)$ and ratio of tannin to protein $\left(\mathrm{x}_{2}\right)$ following the equation:

$$
y=0.698-0.082\left(x_{1}\right)-0.001\left(x_{2}\right)
$$

with $n=16 ; R^{2}=0.40 ; p=0.039$.

The degradation of proteins in the rumen produced the final product of $\mathrm{NH}_{3}$ in this study, the kinetic $\mathrm{NH}_{3}-\mathrm{N}$ rumen in Fig. 2 showed an increase in $\mathrm{NH}_{3}-\mathrm{N}$ concentration in the rumen from $3 \mathrm{~h}$ of incubation and the highest at $48 \mathrm{~h}$ of incubation. $\mathrm{NH}_{3}-\mathrm{N}$ concentrations were significantly higher in controls than those treated with GLR addition.

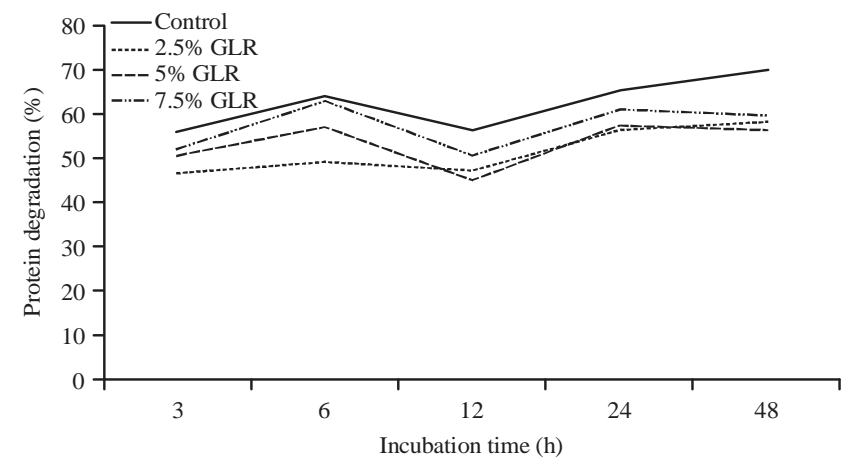

Fig. 1: Effect of gambier leaf residue (GLR) level in cattle feed supplement to ruminal protein degradation

Table 2: In vitro rumen digestibility of cattle feed supplement with addition gambier leaf residue

\begin{tabular}{|c|c|c|c|c|c|c|}
\hline \multirow[b]{2}{*}{ Parameters } & \multicolumn{4}{|c|}{ Gambier leaf residue (DM) (\%) } & \multirow[b]{2}{*}{ SEM } & \multirow[b]{2}{*}{ p-value } \\
\hline & 0 & 2.5 & 5.0 & 7.5 & & \\
\hline Sample protein $(\mathrm{mg} / 100 \mathrm{~mL})$ & 165.66 & 168.14 & 169.75 & 170.96 & & \\
\hline Crude protein degradation (\%) & $69.87^{a}$ & $58.18^{b}$ & $56.37^{b}$ & $59.76^{b}$ & 2.96 & 0.046 \\
\hline RUDP (mg/100 mL) & $49.91^{b}$ & $70.31^{\mathrm{a}}$ & $74.07^{\mathrm{a}}$ & $68.80^{\mathrm{a}}$ & 2.34 & $<0.01$ \\
\hline TCA-soluble $\mathrm{N}(\mathrm{mg} / 100 \mathrm{~mL})$ & $319.14^{b}$ & $345.46^{\mathrm{b}}$ & $465.20^{\mathrm{a}}$ & $433.16^{\mathrm{a}}$ & 26.01 & 0.010 \\
\hline $\mathrm{NH}_{3}-\mathrm{N}(\mathrm{mg} / 100 \mathrm{~mL})$ & $15.17^{\mathrm{a}}$ & $14.75^{\mathrm{b}}$ & $13.95^{\mathrm{b}}$ & $13.11^{\mathrm{b}}$ & 0.33 & 0.049 \\
\hline Peptide N (mg/100 mL) & $304.40^{\mathrm{b}}$ & $330.29^{b}$ & $451.25^{\mathrm{a}}$ & $420.75^{\mathrm{a}}$ & 25.82 & 0.026 \\
\hline $\mathrm{pH}$ & 6.85 & 6.95 & 6.93 & 6.95 & 0.03 & 0.088 \\
\hline
\end{tabular}

Different superscripts on the same line significantly different $(p<0.05)$. RUDP: Rumen undegraded dietary protein, TCA: Trichloroacetic acid 
Int. J. Zool. Res., 15 (1): 6-12, 2019

Table 3: Estimated value of the optimum GLR level in CFS to obtain the minimum protein degradation rate in the incubation period

\begin{tabular}{|c|c|c|c|c|c|c|c|}
\hline Incubation (h) & $\mathrm{b}_{1}$ & $\mathrm{~b}_{2}$ & $a$ & $\mathrm{R}^{2}$ & $P$ & GLR optimum (\%) & Deg. $\min \left(\% \mathrm{jam}^{-1}\right)$ \\
\hline 3 & 0.0021 & -0.0178 & 0.1873 & 0.991 & $<0.01$ & 4.64 & 14.99 \\
\hline 6 & 0.001 & -0.0086 & 0.094 & 0.994 & $<0.01$ & 4.71 & 7.57 \\
\hline 12 & 0.0007 & -0.0051 & 0.0524 & 0.782 & 0.091 & 4.89 & 4.42 \\
\hline 24 & 0.0002 & -0.0017 & 0.027 & 0.947 & 0.032 & 5.02 & 2.35 \\
\hline 48 & 0.0001 & -0.0013 & 0.0145 & 0.961 & 0.021 & 5.12 & 1.05 \\
\hline
\end{tabular}

D: Estimated value of protein degradation based on quadratic equation, $D: b_{1} x^{2}+b_{2} x+a, b_{1}$ and $b_{2}$ : Regression coefficient, a: Intercept, $x$ : Level of GLR, $R^{2}:$ Coefficient of determination, P: Significance of the regression equation and Deg. (min): Minimum degradation rate of protein

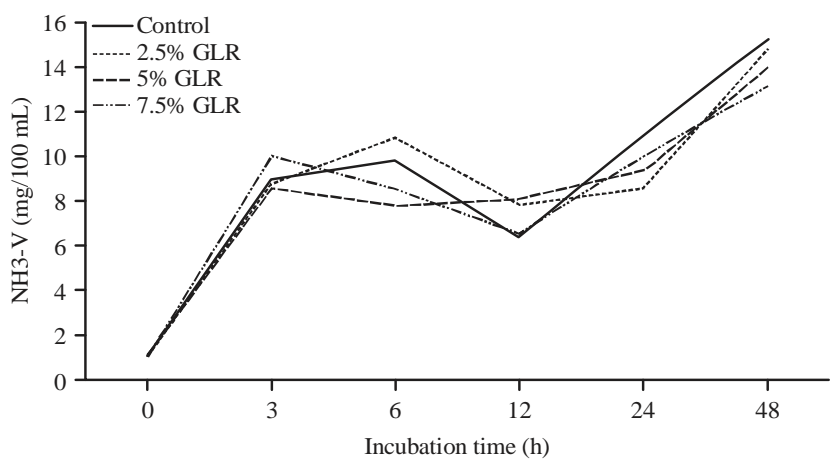

Fig. 2: Kinetik ruminal $\mathrm{NH}_{3}-\mathrm{N}$ as effect of gambier leaf residu (GLR) level in cattle feed supplement

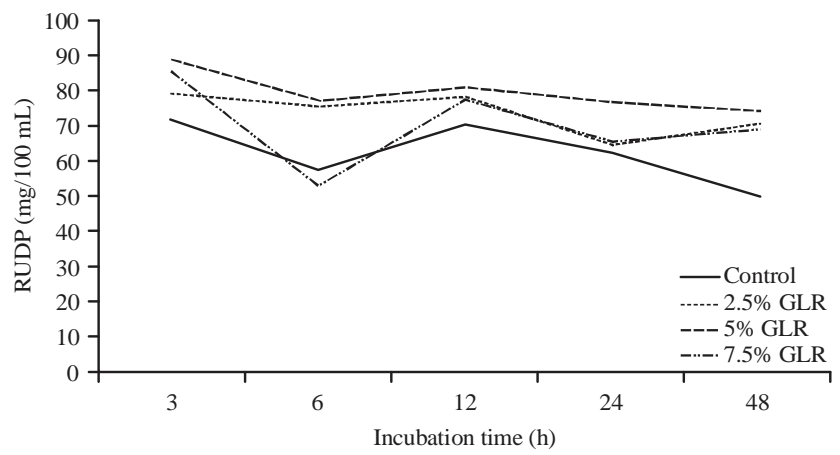

Fig. 3: Rumen undegraded dietary protein (RUDP) as effect of gambier leaf residue (GLR) level in cattle feed supplement

RUDP and peptide N: Table 2 shows the addition of GLR caused an increase in rumen undegraded dietary protein (RUDP) from CFS $(p<0.01)$ compared to controls. The increase in RUDP an average of $42.38 \%$ and began to occur at the lowest level and did not differ statistically to a higher level. Figure 3 shows a 5-7.5\% GLR level produces consistently higher RUDP than the $2.5 \%$ GLR level at all observed incubation times.

The final observation on $48 \mathrm{~h}$ of incubation showed that the TCA-soluble N increased significantly at the $5-7.5 \%$ GLR level. Figure 4 shows that the $5-7.5 \%$ GLR level in the CFS produced the highest TCA-soluble $\mathrm{N}$ and was consistent at all

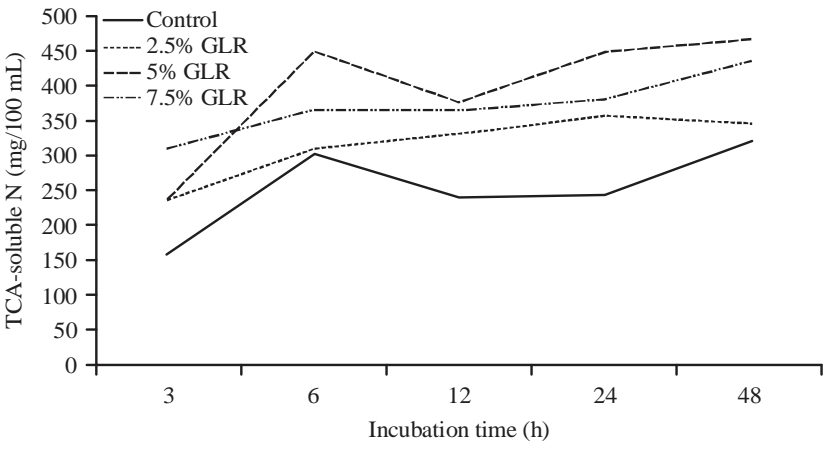

Fig. 4: Effect of gambier leaf residue (GLR) level in cattle feed supplement to TCA-soluble $\mathrm{N}$

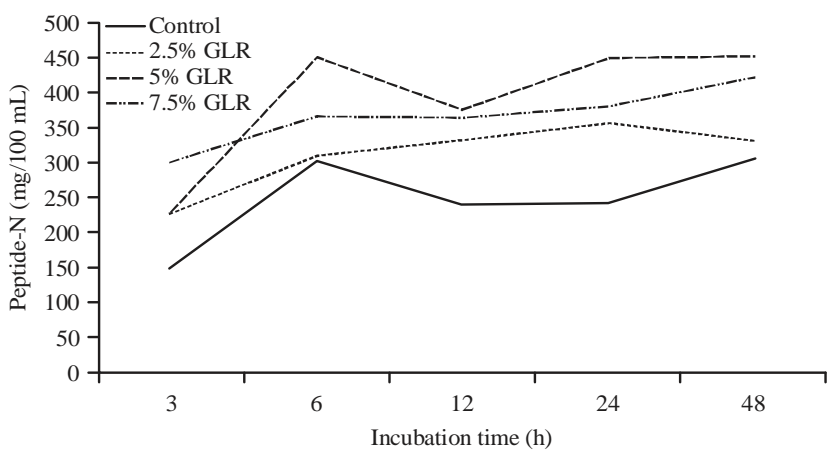

Fig. 5: Effect of gambier leaf residue (GLR) level in cattle feed supplement to ruminal peptide- $\mathrm{N}$

times incubation. The difference of TCA-soluble $\mathrm{N}$ and $\mathrm{NH}_{3}-\mathrm{N}$ is part of the peptide produced during rumen fermentation. The peptides were produced highest on CFS which received an additional GLR at the level of 5-7.5\%. Likewise, the results of the observations in Fig. 5 show the highest peptide results at this level.

Optimum level of GLR: Table 3 shows the pattern of CFS protein degradation in the rumen with the addition of GLR. Protein degradation can be estimated through the quadratic regression equation:

$$
\mathrm{D}=\mathrm{b}_{1} \mathrm{x}^{2}+\mathrm{b}_{2} \mathrm{x}+\mathrm{a}
$$


with a high correlation ( $R^{2}$ ranged $0.782-0.994 ; p<0.05$ ). Results of regression analysis showed that optimum GLR addition ranged $4.64-5.12 \%$ of CFS dry matter $(p<0.05)$. Based on the estimate the optimum level of addition of GLR in CFS above will result in a minimum protein degradation rate of $1.05-$ $14.99 \% \mathrm{~h}^{-1}$, the highest rate will occur at $3 \mathrm{~h}$ incubation and the lowest rate at $48 \mathrm{~h}$ incubation.

\section{DISCUSSION}

This study has decreased the degradation of protein in the rumen due to the addition of GLR starting at the level of $2.5-7.5 \%$. The GLR protects protein occurs due to the GLR contain condensed tannin compounds in which these compounds are able to bind proteins by form a tannin-protein complex that is resistant to proteolytic enzymes from rumen microbes ${ }^{16,17}$. Condensed tannin effect of grape seed, myrabolan, sumach and valonea in grass silage was reported to reduce protein degradation in the rumen in vitro to $74.5-79.1 \%$ compared to $80.8 \%$ in control $^{18}$. Condensed tannins are able to bind proteins due to having the large number of phenolic groups that can bind to the peptide carbonyl ${ }^{10}$. The bonds of tannin with proteins are reversible bonds influenced by $\mathrm{pH}$ in the form of free radical hydrogen bonds of phenolic groups with amide group oxygen ${ }^{19}$. Besides, that tannin compounds inhibit the growth of proteolysis bacteria ${ }^{20}$ and inhibit the activity of proteolytic bacterial enzymes from Butyrivibrio fibrisolvens and Streptococcus bovis ${ }^{21}$.

In the rumen, more than $70 \%$ of the soluble protein is degraded to ammonia $\left(\mathrm{NH}_{3}\right)$ after amino acid deamination ${ }^{22}$. The crude protein in CFS consisted of $15.46 \%$ feed protein and non-protein nitrogen (urea) equivalent to $14.38 \%$ crude protein. High degradation of crude protein at 3 and $6 \mathrm{~h}$ of incubation was hydrolysis of urea to $\mathrm{NH}_{3}$ as evidenced by high $\mathrm{NH}_{3}$ concentration (8.56-9.99 mg/100 mL of rumen fluid) in this period. Hydrolysis of urea to $\mathrm{NH}_{3}$ in the rumen lasts 1-8 $\mathrm{h}$ of incubation with a peak at $2 \mathrm{~h}$ of incubation ${ }^{23,24}$.

The protein degradation value of ration is important to be calculated with respect to the supply of ammonia $\left(\mathrm{NH}_{3}\right)$ for microbial growth. $\mathrm{NH}_{3}-\mathrm{N}$ concentrations in this study both control and treatment were in the optimal supply of $\mathrm{NH}_{3}-\mathrm{N}$ for rumen microbial growth in the range of $2-25 \mathrm{mg} \mathrm{NH}_{3}-\mathrm{N} / 100 \mathrm{~mL}$ rumen fluit ${ }^{25}$, with a minimum supply of $5 \mathrm{mg} / 100 \mathrm{~mL}^{26}$. The resulting ammonia is immediately used by the rumen microbes as nitrogen for microbial protein synthesis ${ }^{23}$. The concentration of $\mathrm{NH}_{3}-\mathrm{N}$ required for optimal rumen microbial growth ${ }^{27}$ is $11.92-13.95 \mathrm{mg} / 100 \mathrm{~mL}$. In this study, $\mathrm{NH}_{3}-\mathrm{N}$ concentration is relatively constant at 3-24 h incubation showed $\mathrm{NH}_{3}-\mathrm{N}$ supply from protein degradation is balanced with microbial requirements, whereas at $48 \mathrm{~h}$ incubation there is an increase in $\mathrm{NH}_{3}-\mathrm{N}$ due to low usage because the rate of microbial protein synthesis is also low in this period ${ }^{24}$.

The RUDP is a part of protein feed that can be available in post-rumen as a protein bypass for ruminant, while the degraded one turns into ammonia $\left(\mathrm{NH}_{3}\right)$ which will be used by rumen microbes. In this study, the rumen $\mathrm{pH}$ was not significantly different by the GLR levels. Condensed tannin form complex bonds with proteins at neutral $\mathrm{pH}$ in the rumen which causes an increase in RUDP as a protein that is released from degradation into the abomasum ${ }^{28,29}$. The tannin-protein complex is available as a protein bypass ${ }^{30}$ of $40-60 \%$. The flow of tannin-protein complexes increases the supply of peptides and amino acids in the small intestine ${ }^{29}$. The tannin-protein complex can be decomposed due to changes in $\mathrm{pH}$ in the abomasum and small intestine ${ }^{31}$, so that it can be digested and absorbed by the ruminant.

The GLR increased TCA-soluble N concentrations in all incubation periods. TCA-soluble $N$ is a combination of nitrogen derived from feed proteins that escape degradation and protein from microbes in the form of peptides, amino acids and ammonia ${ }^{7}$. The increase in TCA-soluble $\mathrm{N}$ occurs due to the increase in protein feed that escapes degradation (RUDP). Peptides and amino acids, in this case are called peptides alone which are part of the protein that will carry the flow of feed from the rumen to the small intestine to be digested and absorbed by the body of the ruminant. Peptide $\mathrm{N}$ is a degradable protein-tannin complex which will break down into proteins and free tannins when in the abomasum ( $\mathrm{pH}$ 2.5-3.5) and small intestine $(\mathrm{pH} 8-9)^{32}$, so protected feed protein can be used by ruminants.

This study obtained the optimum GLR addition is $4.88 \%$ of CFS dry matter and minimized protein degradation in the rumen. At this optimum level, CFS containing condensed tannin 1.09-1.20\%. Other researchers reported lower levels of optimal condensed tannin, $0.50 \%$ in coconut cake ${ }^{33}$ and $0.6 \%$ tannin condensed in soybean mea ${ }^{34}$. Condensed tannin levels used in many studies to protect protein in the rumen are divided into low levels (1-2\%), moderate levels (2-4\%) and high levels of more than $4 \%{ }^{10}$. The optimum level of tannins in this study was classified as a low level of $1.14 \%$ tannins in CFS with a ratio of tannin/protein non-urea is $1 / 31.21$ or $1 \mathrm{~g}$ condensed tannin is able to bind $31.21 \mathrm{~g}$ protein. This finding is almost the same as the report of Sasongko et al. ${ }^{35}$ that, $1 \mathrm{~g}$ of tannin contained in jackfruit leaves can bind $28.89 \mathrm{~g}$ protein of bovine serum albumin. 


\section{CONCLUSION}

The addition of GLR in CFS can reduce the degradation of protein in the rumen, increase RUDP, increase TCA-soluble N and higher Peptide $\mathrm{N}$ will be available for post-rumen digestion. The content of condensed tannin and the ratio of tannins/protein in CFS correlated with protein degradation in the rumen and had a positive impact in increasing the utilization of protein from CFS for cattle. The optimum level of addition of GLR is $4.88 \%$ of CFS dry matter that obtains the minimum protein degradation rate in the rumen.

\section{SIGNIFICANCE STATEMENT}

This study demonstrates that gambier leaf residue (GLR) is able to protect feed proteins from microbial degradation in the rumen and increase the peptides that will be available in post-rumen digestion. This study will help researchers identify critical aspects of protein protection through the addition of GLR to cattle feed supplements, which was previously unexplored. This will allow a new hypothesis about cattle feed supplementations with the addition of GLRs be developed.

\section{ACKNOWLEDGMENTS}

We thanks to the Ministry of Research, Technology and Higher Education of the Republic of Indonesia has funded this research with contract number:050/SP2H/LT/DRPM/2018. Then our thanks for the laboratory of Agricultural Polytechnic of Payakumbuh and Laboratory Ruminant Nutrition of Andalas University which has facilitated this research.

\section{REFERENCES}

1. Lazzarini, I., E. Detmann, M.F. Paulino, S.D.C.V. Filho and R.F.D. Valadares et al., 2013. Nutritional performance of cattle grazing on low-quality tropical forage supplemented with nitrogenous compounds and/or starch. Rev. Brasil.Zootecnia, 42: 664-674.

2. Evitayani, L.W., A. Fariani, T. Ichinohe and T. Fujihara, 2004. Study on nutritive value of tropical forages in North Sumatra, Indonesia. Asian-Aust. J. Anim. Sci., 17: 1518-1523.

3. Ramaiyulis, M. Zain, R.W.S. Ningrat and L. Warly, 2018. Interaction effects of cattle feed supplement and concentrate on rumen fermentability and fiber fraction degradability in low-quality forage. Sch. J. Agric. Vet. Sci., 5: 337-342.

4. Krehbiel, C.R., 2014. Invited review: Applied nutrition of ruminants. Fermentation and digestive physiology. Prof. Anim. Scient., 30: 129-139.
5. Orskov, E.R., 1982. Protein Nutrition Ruminants. 2nd Edn., Academic Press Limited, London.

6. Owens, F.N., S. Qi and D.A. Sapienza, 2014. Applied protein nutrition of ruminants-current status and future directions. Prof. Anim. Scient., 30: 150-179.

7. Griswold, K.E., G.A. Apgar, J. Bouton and J.L. Firkins, 2003. Effects of urea infusion and ruminal degradable protein concentration on microbial growth, digestibility and fermentation in continuous culture. J. Anim. Sci., 81:329-336.

8. Patra, A.K. and J.R. Aschenbach, 2018. Ureases in the gastrointestinal tracts of ruminant and monogastric animals and their implication in urea-N/ammonia metabolism: A review. J. Adv. Res., 13: 39-50.

9. Garg, M.R., P.L. Sherasia, B.M. Bhanderi, B.T. Phondba, S.K. Shelke and H.P.S. Makkar, 2013. Effects of feeding nutritionally balanced rations on animal productivity, feed conversion efficiency, feed nitrogen use efficiency, rumen microbial protein supply, parasitic load, immunity and enteric methane emissions of milking animals under field conditions. Anim. Feed Sci. Technol., 179: 24-35.

10. Bunglavan, S.J. and N. Dutta, 2013. Use of tannins as organic protectants of proteins in digestion of ruminants. J. Livest. Sci., 4: 67-77.

11. Ferdinal, N., 2014. A simple purification method of catechin from gambier. Int. J. Adv. Sci. Eng. Inform. Technol., 4: 53-55.

12. Tilley, J.M.A. and R.A. Terry, 1963. A two-stage technique for the in vitro digestion of forage crops. Grass Forage Sci., 18: 104-111.

13. McDougall, E.I, 1948. Studies on ruminant saliva. 1. The composition and output of sheep's saliva. Biochem. J., 43: 99-109.

14. AOAC., 1990. Official Methods of Analysis Association of Official Agriculture Chemist. Agricultural Chemical; Contaminants; Drugs. 15th Edn., Vol. 1, Association of Official Agriculture Chemists Inc., Virginia, USA.

15. IBM., 2016. IBM SPSS Statistics 24 Core System User's Guide. IBM Corporation, USA.

16. Perez-Maldonado, R.A. and B.W. Norton, 1996. The effects of condensed tannins from Desmodium intortum and Calliandra calothyrsus on protein and carbohydrate digestion in sheep and goats. Br. J. Nutr., 76: 515-533.

17. Getachew, G., H.P.S. Makkar and K. Becker, 2000. Tannins in tropical browses: Effects on in vitro microbial fermentation and microbial protein synthesis in media containing different amounts of nitrogen. J. Agric. Food Chem., 48: 3581-3588.

18. Wischer, G., J. Boguhn, H. Steingab, M. Schollenberger and M. Rodehutscord, 2013. Effects of different tannin-rich extracts and rapeseed tannin monomers on methane formation and microbial protein synthesis in vitro. Animal, 7: 1796-1805. 
19. Kumar, R. and M. Singh, 1984. Tannins: Their adverse role in ruminant nutrition. J. Agric. Food Chem., 32: 447-453.

20. Min, B.R., G.T. Attwood, W.C. McNabb, A.L. Molan and T.N. Barry, 2005. The effect of condensed tannins from Lotus corniculatus on the proteolytic activities and growth of rumen bacteria. Anim. Feed Sci. Technol., 121: 45-58.

21. Jones, G.A., T.A. McAllister, A.D. Muir and K.J. Cheng, 1994. Effects of sainfoin (Onobrychis viciifolia scop.) condensed tannins on growth and proteolysis by four strains of ruminal bacteria. Applied Environ. Microbiol., 60: 1374-1378.

22. Barry, T.N. and S.J. Duncan, 1984. The role of condensed tannins in the nutritional value of Lotus pedunculatus for sheep: 1. Voluntary intake. Br. J. Nutr., 51: 485-491.

23. Chizzotti, F.H.M., O.G. Pereira, L.O. Tedeschi, S.C.V. Filho, M.L. Chizzotti, M.I. Leao and D.H. Pereira, 2008. Effects of dietary nonprotein nitrogen on performance, digestibility, ruminal characteristics and microbial efficiency in crossbred steers. J. Anim. Sci., 86: 1173-1181.

24. Kardaya, D., K.G. Wiryawan, A. Parakkasi and H.M. Winugroho, 2010. In vitro slow-release urea contained in rice strawbased diets to increase efficiency of rumen microbial protein synthesis. Indones. J. Anim. Vet. Sci., 15: 105-117.

25. Preston, T.R. and R.A. Leng, 1987. Matching Ruminant Production System with Avalilable Resources in the Tropics and Sub-Tropics. Cornell University, Ithaca, New York, USA., ISBN:9780958829014, Pages: 245.

26. Satter, L.D. and L.L. Slyter, 1974. Effect of ammonia concentration on rumen microbial protein production in vitro. Br. J. Nutr., 32: 199-208.

27. Ramaiyulis, R.W.S. Ningrat, M. Zain and L. Warly, 2019. Optimization of rumen microbial protein synthesis by addition of Gambier leaf residue to cattle feed supplement. Pak. J. Nutr., 18: 12-19.
28. McSweeney, C.S., B. Palmer, R. Bunch and D.O. Krause, 2001. Effect of the tropical forage calliandra on microbial protein synthesis and ecology in the rumen. J. Applied Microbiol., 90: 78-88.

29. Waghorn, G., 2008. Beneficial and detrimental effects of dietary condensed tannins for sustainable sheep and goat production-Progress and challenges. Anim. Feed Sci. Technol., 147: 116-139.

30. Wina, E. and D. Abdurohman, 2005. The formation of 'ruminal bypass protein' (in vitro) by adding tannins isolated from Calliandra calothyrsus leaves or formaldehyde. J. Ilmu Ternak Vet., 10: 274-280.

31. Wang, Y., G.B. Douglas, G.C. Waghorn, T.N. Barry, A.G. Foote and R.W. Purchas, 1996. Effect of condensed tannins upon the performance of lambs grazing Lotus corniculatusand lucerne (Medicago sativa). J. Agric. Sci., 126: 87-98.

32. Komolong, M.K., D.G. Barber and D.M. McNeill, 2001. Postruminal protein supply and $\mathrm{N}$ retention of weaner sheep fed on a basal diet of lucerne hay (Medicago sativa) with increasing levels of quebracho tannins. Animal Feed Sci. Technol., 92: 59-72.

33. Zamsari, M., Sunarso and Sutrisno, 2012. The use of natural tannins in protecting coconut cake protein in terms of protein fermentability in vitro. Anim. Agric. J., 1: 406-410.

34. Subrata, A., L.M. Yusiati and A.Agus, 2005. Utilization of tea pulp tannins on the effects of defaunation, parameters of rumen fermentation and microbial protein synthesis by in vitro. Agrosains, 18: 473-488.

35. Sasongko, W.T., L.M. Yusiati and Z. Bachruddin, 2010. Optimalisation binding of jackfruit leaves tannin with bovine serum albumin protein. Bull. Peternakan, 34: 154-158. 